\title{
Application of the Enzyme-linked Immunosorbent Assay Procedure to the Detection of Grapevine Fanleaf Virus
}

\author{
D. J. ENGELBRECHT \\ Plant Protection Research Institute, Plant Quarantine Station, Stellenbosch 7600 \\ Thanks are due to F. A. de Milander and other members of the Plant Virology Section for their excellent technical assistance.
}

\begin{abstract}
Enzyme-linked immunosorbent assay was used to detect grapevine fanleaf virus (GFV) directly in grapevine leaf tissue. The addition of nicotine or nicotine and sodium diethyldithiocarbamate to the extracting buffer solution greatly enhanced the sensitivity of the procedure and enabled detection of GFV concentrations as low as $12 \mathrm{ng} / \mathrm{m} \ell$. The conjugated GFV gamma-globulin detected the GFV strains, grapevine vein banding and grapevine yellow mosaic but failed to detect the GFV serotype arabis mosaic in grapevine leaf tissue. The technique makes possible the collection and processing of numerous samples throughout the growing season and is, therefore, particularly suitable for studies on the incidence and spread of GFV in the field. It also facilitates the resolution of disease syndromes with which GFV is associated.
\end{abstract}

Grapevine fanleaf virus (GFV) has been known to be present in local vineyards for many years (Engelbrecht, 1961, 1963; Van Regenmortel, 1965) but it is difficult to assess its incidence and spread because GFV often causes symptomless infection in local scion and rootstock cultivars (Engelbrecht, 1979; unpublished). Moreover, existing techniques for the detection and identification of latent GFV infection in grapevine are often insensitive or laborious to perform, and this restricts their use (Belli, et al., 1965; Engelbrecht \& Wolfswinkel, 1967; Uyemoto, et al., 1976). These limitations have been overcome by using the recently described enzyme-linked immunosorbent assay (ELISA) technique for detecting plant viruses (Voller, et $a l .$, 1976). This paper describes the application of ELISA to the detection of GFV in Vitis, and considers the suitability of the method for large-scale use in surveys.

\section{MATERIALS AND METHODS}

The GFV strain used in antiserum production was isolated from a local Vitis vinifera L. cv. Colombar vine showing typical fanleaf symptoms (Engelbrecht, 1972). Virus was cultured in Chenopodium quinoa Willd., clarified and concentrated as described by Martelli \& Hewitt (1963), before final purification by sucrose gradient zonal electrophoresis in an apparatus similar to that used by Van Regenmortel (1964). Such virus preparations were free of normal host constituents detectable serologically, and elicited, upon injection into rabbits over a 10 week period, an antiserum with a titre of $1 / 512$ as determined by gel double diffusion tests (Ouchterlony, 1958). The antiserum showed that its homologous antigen was serologically indistinguishable from a large number of GFV and grapevine vein banding virus (GVBV) isolates, and distantly related, serologically, to an isolate of arabis mosaic virus (AMV) obtained from an imported $V$. vinifera cv. Regina grapevine. Because of erratic transmission of virus to $C$. quinoa, tests with grapevine yellow mosaic virus (GYMV) were restricted to one isolate from a $V$. vinifera $\mathrm{cv}$. Chenin blanc grapevine.

Unless otherwise stated, purification and conjugation of gamma-globulin, as well as the calibration of the polystyrene microtitre plates were carried out as described by
Clark \& Adams (1976: 1977). The gamma-globulin fraction of the antiserum was precipitated with ammonium sulphate, and partially purified on a DEAE-cellulose column, followed by exhaustive dialysis. A portion of the purified gamma-globulin preparation with an $\mathrm{A}_{280}$ of 1,4 and assumed to have a concentration of $1 \mathrm{mg} / \mathrm{m} \ell$ was conjugated to alkaline phosphate (Sigma type VII, Boehringer, Mannheim) with 0,05\% glutaraldehyde. Because of volume changes and possible gamma-globulin losses during the conjugation procedure, concentration of conjugate is given in terms of dilution. The remainder of the gamma-globulin fraction was used for coating the polystyrene microtitre plates. Optimal coating and conjugated gamma-globulin concentrations were determined with GFV-infected $C$. quinoa sap. The conjugated gamma-globulin was incubated for $4 \mathrm{~h}$ at $37^{\circ} \mathrm{C}$. The extinction at $\AA_{405}$ of the contents of each well was recorded $c a .1 \mathrm{~h}$ after adding the enzyme substrate, $p$-nitrophenyf phosphate, to the wells, and the reaction was stopped with $\mathrm{NaOH}$. All readings were made with a 200 $\mu \ell 10 \mathrm{~mm}$ path length flow-through cuvette. Results were judged to be positive if the average $A_{405}$ of a test sample exceeded the $\mathrm{A}_{405}$ of the healthy control sample in the same test plate by a factor of two or more (Voller, Bidwell \& Bartlett, 1977).

Except where stated, all plant extracts for ELISA tests were prepared by grinding $c a$. 0,5 g leaf tissue in a mortar and pestle at 1:10 (m/v) with phosphate-buffered saline solution containing $0,5 \mathrm{~m} \ell / \ell$ Tween $20.20 \mathrm{~g} / \ell(\mathrm{m} / \mathrm{v})$ polyvinyl-pyrrolidone (Mol. Wt. 44000 ) and $2 \mathrm{~g} / \ell$ ovalbumin (Barbara, et al., 1978), and referred to as standard buffer. Ground tissue was usually partially clarified by low speed centrifugation ( $3000 \mathrm{~g}$ for $c a$. $1 \mathrm{~min}$ ), and was used on the same day or was stored at $-20{ }^{\circ} \mathrm{C}$ in sealed tubes for later use. Tests were replicated at least twice in each plate. Healthy and GFV-infected C. quinoa or grapevine leaf samples and buffer controls were included in each plate.

For sap inoculation, grapevine leaf tissue was ground in $1 \%$ nicotine $(1: 3 \mathrm{~m} / \mathrm{v})$ in the presence of $1 \%(\mathrm{~m} / \mathrm{v})$ Celite abrasive. Extracts were then used to inoculate $C$. quinoa leaves, and the plants were kept in a shaded glasshouse at temperatures optimal for successful GFV transmission 
(Engelbrecht \& Wolfswinkel, 1967). Positive transmissions were usually assessed serologically by double diffusion tests in agar, using undiluted sap.

\section{RESULTS}

Purified gamma-globulin calibrated against GFVinfected $C$. quinoa leaf tissue gave excellent differentiation between diseased and healthy leaf tissue at a level of 1,0 $\mu \mathrm{g}$ gamma-globulin/m $\ell$ coating buffer and an enzyme conjugate dilution of 1:800. Virus was still detectable in C. quinoa sap at a dilution of 1:10 $000\left(\mathrm{~A}_{405}=0,18 c f\right.$. healthy $\left.\mathrm{A}_{405}=0,03\right)$. In contrast, GFV was detectable in grapevine leaf tissue only when extraction was done at 1:20 (m/v) dilution despite thorough grinding (Thresh, et al., 1977). However, the addition of either $1 \%(\mathrm{v} / \mathrm{v})$ nicotine or nicotine and $0,2 \%(\mathrm{~m} / \mathrm{v})$ sodium diethyldithiocarbamate to the extracting buffer greatly enhanced the sensitivity of GFV detection in grapevine leaf extract at dilutions of 1:5-1:20 (Table 1). These additives were subsequently incorporated into the standard buffer in all further tests.
ELISA also confirmed the absence of GFV in vines of 26 clones of $V$. vinifera cv. Queen of the Vineyard, showing severe symptoms of grapevine stem-grooving (Engelbrecht, 1973). Similarly, GFV was consistently absent in several $V$. vinifera cultivars, showing symptoms of grapevine yellow speckle and grapevine enations (Engelbrecht, 1979; unpublished).

To determine the distribution of GFV in infected vines, and the minimum leaf sample required for large-scale testing by ELISA, the first fully expanded leaves on growing shoots of GFV-infected $V$. vinifera $\mathrm{cv}$. Colombar vines were collected at random on the vine and from several vines. Each leaf was punched three times, and the resulting $15 \mathrm{~mm}$ discs were macerated at a dilution of 1:10 $(\mathrm{m} / \mathrm{v})$ in standard buffer. Virus appeared to be evenly distributed in all vines tested, for example all 60 single leaf samples, comprising 3-5 shoots on each of 15 vines, were strongly positive (mean $\mathrm{A}_{405}=1,5 c f$. healthy $\mathrm{A}_{405}=$ $0,02)$ in late spring. Furthermore, the presence of GFV could be established reliably by ELISA in as little as $0,1 \mathrm{~g}$ leaf tissue. Similar results were obtained in late autumn but

TABLE 1

Comparison of extracting buffers for the detection of grapevine fanleaf (GFV) virus in grapevine leaf samples ${ }^{a}$

\begin{tabular}{|c|c|c|c|}
\hline \multirow{2}{*}{ Extracting buffer } & \multicolumn{3}{|c|}{ Leaf:buffer ratio $(\mathrm{m} / \mathrm{v})$} \\
\hline & $1: 5$ & $1: 10$ & $1: 20$ \\
\hline 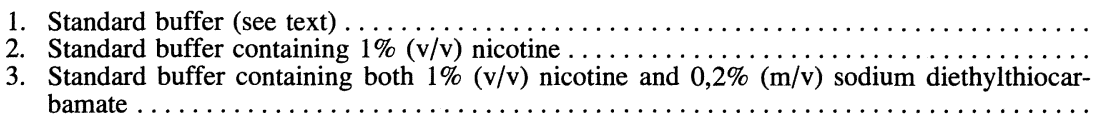 & $\begin{array}{r}0,02^{b} \\
1,15 \\
1,08\end{array}$ & $\begin{array}{l}0,01 \\
0,38 \\
0,78\end{array}$ & $\begin{array}{l}0,10 \\
0,11 \\
0,39\end{array}$ \\
\hline
\end{tabular}

${ }^{a}$ Random $0,5 \mathrm{~g}$ aliquots of leaf tissue from a GFV-infected $V$. vinifera cv. Colombar source

${ }^{b}$ Mean $\mathrm{A}_{405}$ based on 3 samples of each leaf: buffer ratio

The limit of detectable virus in grapevine leaf tissue was determined in dilutions of purified virus in an extract of healthy grapevine sap, prepared at a 1:10 (m/v) dilution. The purified GFV with an $A_{260} / A_{280}$ ratio and an $A_{260}$ of 1,80 and 1,20 respectively, contained $c a .0,12 \mathrm{mg} / \mathrm{m} \ell$ of virus based on an extinction coefficient $\left(\mathrm{E}_{1 \mathrm{~cm}}^{0,1 \%}\right)$ of 10 , suggested by Gibbs \& Harrison (1976) for a virus with about $40 \%$ RNA (Quacquarelli, et al., 1976). An $\mathrm{A}_{405}$ value of 0,03 for a GFV dilution of 1:20000 ( $c a$. 6 $\mathrm{ng} / \mathrm{m} \ell)$ equalled that for a healthy grapevine extract $(1: 10$ $\mathrm{m} / \mathrm{v}$ ). Taken as twice the $\mathrm{A}_{405}$ for healthy control extracts, the limit of detection of GFV was, therefore, at a virus concentration of $c a .12 \mathrm{ng} / \mathrm{m} \ell$.

A comparison between ELISA and sap transmission to $C$. quinoa showed that as soon as active shoot growth on the vine came to an end by early summer, symptom expression in the herbaceous test plants became erratic and inconsistent, whereas ELISA reacted strongly with extracts from vines with grapevine fanleaf symptoms throughout the growing season (Table 2). Furthermore, the ELISA technique was equally successful in detecting GVBV isolates (mean $\mathrm{A}_{405}=0,92$ ) in summer when symptoms were most conspicuous. However, GYMV was only weakly detected in $V$. vinifera $\mathrm{cv}$. Chenin blanc $\left(\mathrm{A}_{405}=0,06 \mathrm{cf}\right.$ healthy $\mathrm{A}_{405}=0,02$ ) soon after bud-break and before symptoms disappeared on new growth. Extracts from the $V$. vinifera cv. Regina vine, containing $A M V$, did not react with the GFV antiserum $\left(\mathrm{A}_{405}=0,02\right)$. samples tended to give weaker reactions (mean $\mathrm{A}_{405}=$ $0,36 c f$. healthy $\mathrm{A}_{405}=0,03$ ).

To investigate possible spread of GFV in a section of an 18-year-old $V$. vinifera $\mathrm{cv}$. Colombar vineyard, comprising 20 rows of 55 vines each, where the presence of Xiphinema index Thorne \& Allen, the vector of GFV (Hewitt, Raski \& Goheen, 1958) was suspected (P. C. Smith, 1979; personal communication), the positions of healthy and infected vines were recorded. The individual vines either did not react or gave strong positive readings (mean $\mathrm{A}_{405}=1,5 c f$. healthy $\mathrm{A}_{405}=0,02$ ), with 140 of the

TABLE 2

Comparison of ELISA (enzyme-linked immunosorbent assay) with saptransmission to Chenopodium quinoa to detect grapevine fanleaf virus in Vitis vinifera $\mathrm{cv}$. Colombar vines

\begin{tabular}{|c|c|c|c|}
\hline \multirow[b]{2}{*}{ Date } & \multirow{2}{*}{$\begin{array}{l}\text { No. vines } \\
\text { tested }\end{array}$} & \multicolumn{2}{|c|}{ No. vines positive } \\
\hline & & $\begin{array}{l}\text { Sap trans- } \\
\text { mission }^{a}\end{array}$ & $\mathrm{ELISA}^{b}$ \\
\hline $\begin{array}{l}\text { October } 1978 \ldots \ldots \\
\text { November } 1978 \ldots \ldots \\
\text { December } 1978 \ldots \ldots \\
\text { January } 1979 \ldots \ldots \\
\text { February } 1979 \ldots \ldots \\
\text { March } 1979 \ldots \ldots \\
\text { April } 1979 \ldots \ldots\end{array}$ & $\begin{array}{l}10 \\
10 \\
10 \\
10 \\
10 \\
10 \\
10\end{array}$ & $\begin{array}{r}10 \\
10 \\
4 \\
0 \\
0 \\
2 \\
0\end{array}$ & $\begin{array}{l}10 \\
10 \\
10 \\
10 \\
10 \\
10 \\
10\end{array}$ \\
\hline
\end{tabular}

${ }^{a}$ Eight $C$. quinoa plants inoculated with extract from each vine

${ }^{b}$ Mean $\mathrm{A}_{405}$ at least twice that of healthy grapevine extract 
1049 surviving vines infected. In preliminary bulk sampling tests with some of these vines it was found that antigens could still be detected when only one out of 20 vines was infected (mean $A_{405}=0,25$ ). Moreover, freezing of the extracts for $24 \mathrm{~h}$ or longer ( 8 weeks) did not significantly reduce antigen activity. The null hypothesis of a random distribution of diseased plants was used to compare the observed number of doublets (two adjacent diseased vines) and an expected number $d$ as computed by the expression given by Van der Plank (1947):

$$
\mathrm{d}=\frac{\mathrm{u}(\mathrm{u}-1)}{\mathrm{n}}
$$

where $\mathrm{n}$ is the total number of vines examined, and $\mathrm{u}$ the number of diseased vines. The observed number was 26 , the computed expected number 18,5 , with a standard error of 4,3 .

\section{DISCUSSION}

In the past, GFV could not be detected serologically directly in the grapevine unless the virus present was first concentrated or transmitted to $C$. quinoa (Vuittenez, 1970). It was, therefore, difficult to establish the incidence and spread of this soil-borne virus. The modified ELISA procedure described here has demonstrated that GFV can be detected consistently in large numbers of grapevines with negligible background values for healthy extracts. However, the inability of the GFV antiserum to detect AMV, and its weak reaction to GYMV suggest limitations in this assay procedure which can be overcome only by concurrent tests with antisera produced against known serological strains (Barbara et al., 1978). The modified ELISA procedure will also greatly help to resolve uncertainties regarding the possible role of GFV in disease syndromes. For instance, the assumption that grapevine stem grooving disease is caused by a strain of GFV (Hewitt, et al., 1970) has been refuted in the present study. Furthermore, no support could be found for a possible role of GFV in the enations syndrome (Graniti \& Martelli, 1970) of local cultivars. The pattern of GFV occurrence in the Colombar vineyard was consistent with random distribution, indicating no spread of GFV and, therefore, also the absence of the nematode vector, $X$. index, from the plot. However, $X$. index has been reported from several vineyard sites in the Western Cape Province (Heyns, 1971; P. C. Smith, 1979; personal communication), and preliminary findings indicate that spread of GFV in a replanted vineyard is correlated with the presence of this nematode (Engelbrecht, 1979; unpublished).

Extracts from several woody plants have shown reduced ELISA reactions (Clark \& Adams, 1976). In most cases the inhibition could be overcome by further dilution with the extracting buffer. In the present study the inhibiting effect of the grapevine leaf extract was partially overcome by dilution but the reaction lost most of its sensitivity. This may account for the inability of ELISA to detect peach rosette mosaic virus in some $V$. labruscana Vaily cv. Concord grapevines (Ramsdell, et al., 1979). The beneficial effect of sodium diethylidithiocarbamate in the detection of apple chlorotic leafspot virus in apple has recently been reported (Flegg \& Clark, 1979), and explained as a possible stabilisation of the virus against salt-induced breakdown. The ameliorating effect of both nicotine and sodium diethyldithiocarbamate in the present study may be due in part to the action of these substances on tannins and other phenolic compounds present in grapevine tissue, as was pointed out by Kosuge (1965).

\section{REFERENCES}

BARBARA, D. J., CLARK, M. F., THRESH, J. M. \& CASPER, R., 1978. Rapid detection and serotyping of prunus necrotic ringspot virus in perennial crops by enzyme-linked immunosorbent assay. Ann. appl. Biol. 90, 395-399.

BELLI, G., REFATTI, E., CESATI, R. \& CONSINI, G., 1965. Comparison of grape indicators and herbaceous hosts in detecting grapevine soil-borne viruses. Proc. Int. Conf. Virus and Vector on Perennial Hosts. Davis, Calif., pp. $371-377$.

CLARK, M. F. \& ADAMS, A. N., 1976. Laboratory notes on the ELISA technique. East Malling Res. Stn., Maidstone, Kent. $6 \mathrm{pp}$

CLARK, M. F. \& ADAMS, A. N., 1977. Characteristics of the microplate method of enzyme-linked immunosorbent assay for the detection of plant viruses. J. gen. Virol. 34, 475483.

ENGELBRECHT, D. J., 1961. A graft-transmissible disease resembling fanleaf of grapevines. S. Afr. J. agric. Sci. 4, $631-633$

ENGELBRECHT, D. J., 1963. Sap transmission of viruses from pear, grapevine and bramble to herbaceous hosts. S. Afr. J. Lab. Clin. Med., 9, 140-141.

ENGELBRECHT, D. J. \& WOLFSWINKEL, L. D., 1967. Chenopodium as host to viruses transmitted from apple, pear and grapevine. S. Afr. J. agric. Sci. 10, 419-428.

ENGELBRECHT, D. J., 1972. Virussiektes van die druifvoorkoms en uitskakeling. Die Wynboer, No. 493, October, $14-16$.

ENGELBRECHT, D. J., 1973. Effect of stem-grooving on yield of young "Queen of the Vineyard" table grapes (Vitis vinifera L.) grafted on a tolerant rootstock. Riv. Patol. Veg., S. IV, 9, 236-242.

FLEGG, CAROLINE L. \& CLARK, M. F., 1979. The detection of apple chlorotic leafspot virus by a modified procedure of enzyme-linked immunosorbent assay (ELISA). Ann. appl. Biol. 91, 61-65.

GIBBS, A. \& HARRISON, B., 1976. Plant Virology: The principles. Edward Arnold (Publishers) Ltd. London, p. 115.

GRANITI, A. \& MARTELLI, G. P., 1970. Enations. In: Virus diseases of small fruits and grapevines. Univ. Calif. Berkeley, Calif. USA., pp. 241-243.

HEWITT, W. B., RASKI, K. J. \& GOHEEN, A. C., 1958. Nematode vector of soil-borne fanleaf virus of grapevines. Phytopathology 48, 586-595.

HEWITT, W. B., MARTELLI, G. P., DIAS, H. F. \& TAYLOR, R. H., 1970. Grapevine fanleaf virus. C.M.I.|A.A.B. Descriptions of plant viruses No. 28.

HEYNS, J., 1971. Three Xiphinema species from the South Western Cape Province (Nematode: Longidoridae). Phytophylactica 3, 107-114.

KOSUGE, T., 1965. Biochemical aspects of virus inhibitors in vivo and in vitro. Proc. Int. Conf. on Virus and Vector on perennial hosts, with special reference to vitis. pp. 274-254.

MARTELLI, G. P. \& HEWITT, W. B., 1963. Purification and serology of an Italian strain of grape fanleaf virus (GFV). Phytopath. Medit. 2, 285-294.

OUCHTERLONY, O., 1958. Diffusion-in-gel methods for immunological analyses. In: Progress in allergy 5: 1-78. S. Karger, Basel and New York.

QUACQUARELLI, A., GALLITELLI, D., SAVINO, V. \& MARTELLI, G. P., 1976. Properties of grapevine fanleaf virus. J. gen Virol. 32, 349-360.

RAMSDELL, D. C., ANDREWS, REBECCA, W., GILLETT, JERRI M. \& MORRIS, CINDY E., 1979. A comparison between enzyme-linked immunosorbent assay (ELISA) and 
Chenopodium quinoa for detection of peach rosette mosaic virus in "Concord" grapevines. Plant Dis. Reptr. 63, 74-77.

THRESH, J. M., ADAMS, A. N., BARBARA, D. J. \& CLARK, M. F., 1977. The detection of three viruses of hop (Humulus lupulus) by enzyme-linked immunosorbent assay (ELISA). Ann. Appl. Biol. 87, 57-65.

UYEMOTO, J. K., GOHEEN, A. C., LUHN, C. F. \& PETERSEN, L. J., 1976. The use of Chenopodium quinoa in indexing for grapevine fanleaf virus. Plant Dis. Reptr. 60, 536-538.

VAN DER PLANK, J. E., 1947. A method for estimating the number of random groups of adjacent diseased plants in a homogeneous field. Trans. R. Soc. S. Afr. 31, 269-278.

VAN REGENMORTEL, M. H. V., 1964. Purification of plant viruses by zone electrophoresis. Virology. 23, 495-502.
VAN REGENMORTEL, M. H. V. 1965. Purification of South African isolates of grapevine fanleaf virus by zone electrophoresis. Proc. Int. Conf. on Virus and Vector on perennial hosts, with special reference to Vitis. University of California, pp. 410-416.

VOLLER, A., BARTLETT, A., BIDWELL, D. E., CLARK, M. F. \& ADAMS, A. N., 1976. The detection of viruses by enzyme-linked immunosorbent assay (ELISA). J. gen. Virology. 33, 165-167.

VOLLER, A., BIDWELL, D. E., \& BARTLETT, A., 1977. The enzyme-linked immunosorbent assay. Flowline Press, Guernsey, UK., $48 \mathrm{p}$.

VUITTENEZ, A., 1970. Fanleaf of grapevine. In: Virus diseases of small fruit and grapevines. Univ. Calif. Berkeley, Calif. USA., pp. 217-228. 